\title{
Karyotypic characterization of Symphurus tessellatus and Symphurus plagusia (Pleuronectiformes, Cynoglossidae) from Brazilian coastal waters
}

\author{
H.M.M. Teixeira ${ }^{1}$, J.A. Bitencourt ${ }^{1}$, R.C.T. Ramos ${ }^{2}$ and P.R.A.M. Affonso ${ }^{1}$ \\ ${ }^{1}$ Departamento de Ciências Biológicas, Universidade Estadual do Sudoeste \\ da Bahia, Jequié, BA, Brasil \\ ${ }^{2}$ Departamento de Sistemática e Ecologia, Universidade Federal da Paraíba, \\ João Pessoa, PB, Brasil
}

Corresponding author: P.R.A.M. Affonso

E-mail: paulomelloaffonso@yahoo.com.br

Genet. Mol. Res. 20 (4): gmr19000

Received December 02, 2021

Accepted December 20, 2021

Published December 28, 2021

DOI http://dx.doi.org/10.4238/gmr19000

\begin{abstract}
The family Cynoglossidae (tonguefishes) is a speciose group of Pleuronectiformes, encompassing about $20 \%$ of described species in this order, distributed among three genera (Cynoglossus, Paraplagusia and Symphurus). Symphurus is the only genus of tonguefish in the Western Atlantic, being characterized by species complexes and cryptic forms; consequently the actual species richness of this genus is likely to be underestimated. Comparative cytogenetic studies have proved to be useful to resolve taxonomic uncertainties in ichthyofauna. Therefore, we carried out the karyotypic characterization of Symphurus tessellatus and Symphurus plagusia from the Brazilian coast based on conventional analysis, Cbanding, silver nitrate (Ag-NORs) and base-specific fluorochrome staining. The specimens of $S$. tessellatus presented $2 \mathrm{n}=46,20$ $\mathrm{m} / \mathrm{sm}+26 \mathrm{st} / \mathrm{a}$, differing from that previously reported $(2 \mathrm{n}=46$, $22 \mathrm{~m} / \mathrm{sm}+24 \mathrm{st} / \mathrm{a}$ ), with heterochromatic blocks in the centromeric region of most chromosomes, as usually described in this group. We also found interstitial segments on the long arms of the third chromosome; these were coincident to Ag-NORs and GC-rich sites.
\end{abstract}


In S. plagusia, the karyotype is composed of $32 \mathrm{~m} / \mathrm{sm}+14 \mathrm{st} / \mathrm{a}(2 \mathrm{n}=46)$, with a single nucleolar organizer regions (NORs) system, which is the first cytogenetic data for this species. The unique karyotype formulae of these two species suggest that pericentric inversions played a major role in the chromosomal differentiation of tonguefishes, being useful for cytotaxonomy and diagnosis of evolutionary units in Symphurus.

Key words: Tonguefishes; Symphurus; Karyotype; Cytotaxonomy

\section{INTRODUCTION}

The genus Symphurus is widely distributed, being the only representative of the family Cynoglossidae from the Western Atlantic Ocean (Figueiredo and Menezes, 2000). A total of 81 species are recognized within Symphurus (Lee et al., 2017), with nine valid species for the Brazilian coast (Western South Atlantic): $S$. diomedeanus; $S$. ginsburgi; $S$. jenynsi; S. kyaropterygium; S. marginatus; S. plagusia; S. tessellatus; S. trewavasae; and S. oculellus. Nonetheless, the taxonomy of this group of tonguefishes remains controversial, including polymorphic taxa and species complexes. The imprecise morphological identification of Symphurus species is related to overlapping of meristic data in identification keys of Cynoglossidae (Figueiredo and Menezes, 2000) and the need of incorporation of oesteological, structural, and pigmentation data to their diagnosis (Munroe, 1991).

From this perspective, other data besides anatomical features should be incorporated to provide a proper delimitation of species or unique evolutionary lineages (Padial et al., 2010). The cytogenetic analyses, even though neglected in recent studies, are highly informative to interspecific comparisons, particularly in fishes (Cipriano et al., 2008; Kasahara, 2009; Argolo et al., 2018). Once chromosomal differences are able to impose reproductive isolation by gamete unbalance, unviability or sterility of hybrids (Allendorf and Luikart, 2007), chromosomal markers are useful to taxonomic inferences and to infer genome evolution of distinct groups (Cioffi et al., 2011).

However, most of marine fish species still lack basic karyotypic information. In Pleuronectiformes, cytogenetic reports are available for about 60 out of the 822 valid species (Azevedo et al., 2007), representing less than $10 \%$ of the recognized taxa from this order. Even though, this number has increased over the last years (Bitencourt et al., 2014; Bitencourt et al., 2017), the cytogenetic reports in this fish group remain underrepresented. In Cynoglossidae, cytogenetic data are restricted to less than 5\% of species, including two representatives of the genus Symphurus (Le Grande, 1975; Azevedo et al., 2007).

Even though scarce, the available chromosomal data in Cynoglossidae (Table 1) indicate a remarkable genomic plasticity, with diploid numbers ranging from 34 to 46 , as well as distinct sex chromosome systems such as ZZ/ZW in Cynoglossus semilaevis $(2 \mathrm{n}=$ 42) (Jiang et al., 2014) and $\mathrm{X}_{1} \mathrm{X}_{1} \mathrm{X}_{2} \mathrm{X}_{2} / \mathrm{X}_{1} \mathrm{X}_{2} \mathrm{Y}$ in Symphurus plagiusa $(2 \mathrm{n}=45 / 46)$ (Le Grande, 1975). These data reinforce the role of chromosomal evolution during the speciation of tonguefishes, suggesting that cytogenetics might be useful to identify their representatives in comparative analyses. 
Therefore, the goal of the present study was to cytogenetically characterize populations of $S$. tessellatus and S. plagusia from northeastern and southeastern Brazilian coastal waters and evaluate the efficiency of chromosomal markers in cytotaxonomy of tonguefishes.

\section{MATERIAL AND METHODS}

Eight specimens of Symphurus were collected along the northeastern and southeastern coast of Brazil according to the license provided by Instituto Chico Mendes de Conservação da Biodiversidade - ICMBIO (SISBIO 31360-1). The individuals were identified as Symphurus tesselatus and S. plagusia (Figure 1) by experts and deposited in the fish collection from Universidade Federal da Paraíba (voucher UFPB 9851).

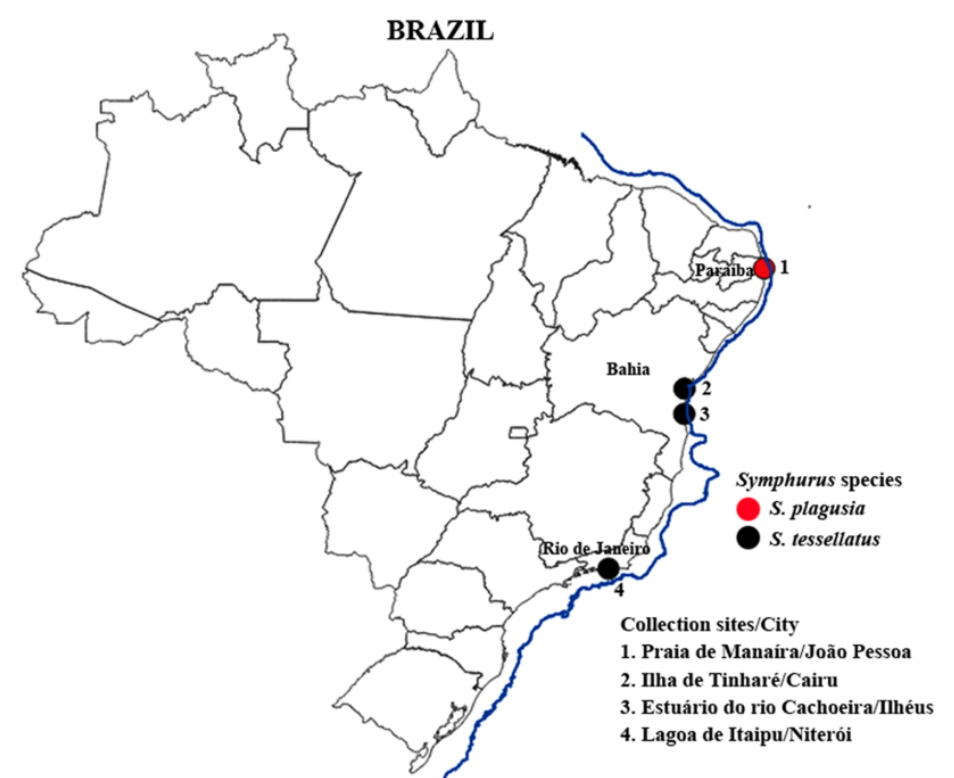

Figure 1. Map showing the collection sites (indicated by numbers) of S. tesselatus (red circle) and S. plagusia (black circle) in northeastern and southeastern coast of Brazil.

After euthanasia in iced water (Blessing et al., 2010), kidney fragments were removed to obtain mitotic chromosomes as proposed by Netto et al. (2007). All procedures were approved by the Committee of Ethics in Animal Utilization of the Universidade Estadual do Sudoeste da Bahia - UESB (CEUA/UESB n 71/2014).

The chromosomal morphology was established based on arm ratios (Levan et al., 1964) and classified into metacentric/submetacentric $(\mathrm{m} / \mathrm{sm})$ and subtelocentric/acrocentric (st/a). The heterochromatin was visualized by C-banding according to Sumner (1972), with slight modifications. Active nucleolar organizer regions (NORs) were identified by silver nitrate staining (Ag-NOR) (Howell and Black, 1980) and base-specific fluorochrome staining was used to detected GC- and AT-rich sites using chromomycin $\mathrm{A}_{3}\left(\mathrm{CMA}_{3}\right)$, distamycin (DA) and 4,6-diamidino-2-phenylindole (DAPI), respectively (Schweizer, 1980). 


\section{RESULTS}

All specimens of $S$. tessellatus and S. plagusia shared a modal diploid number of $2 \mathrm{n}$ $=46$, but they differed in relation to their karyotype formulae, being equal to 20 $\mathrm{m} / \mathrm{sm}+26 \mathrm{st} / \mathrm{a}$ (Figure $2 \mathrm{~A}$ ) and $32 \mathrm{~m} / \mathrm{sm}+14 \mathrm{st} / \mathrm{a}$ (Figure $2 \mathrm{~B}$ ), respectively. Heteromorphic sex chromosomes were not evidenced.

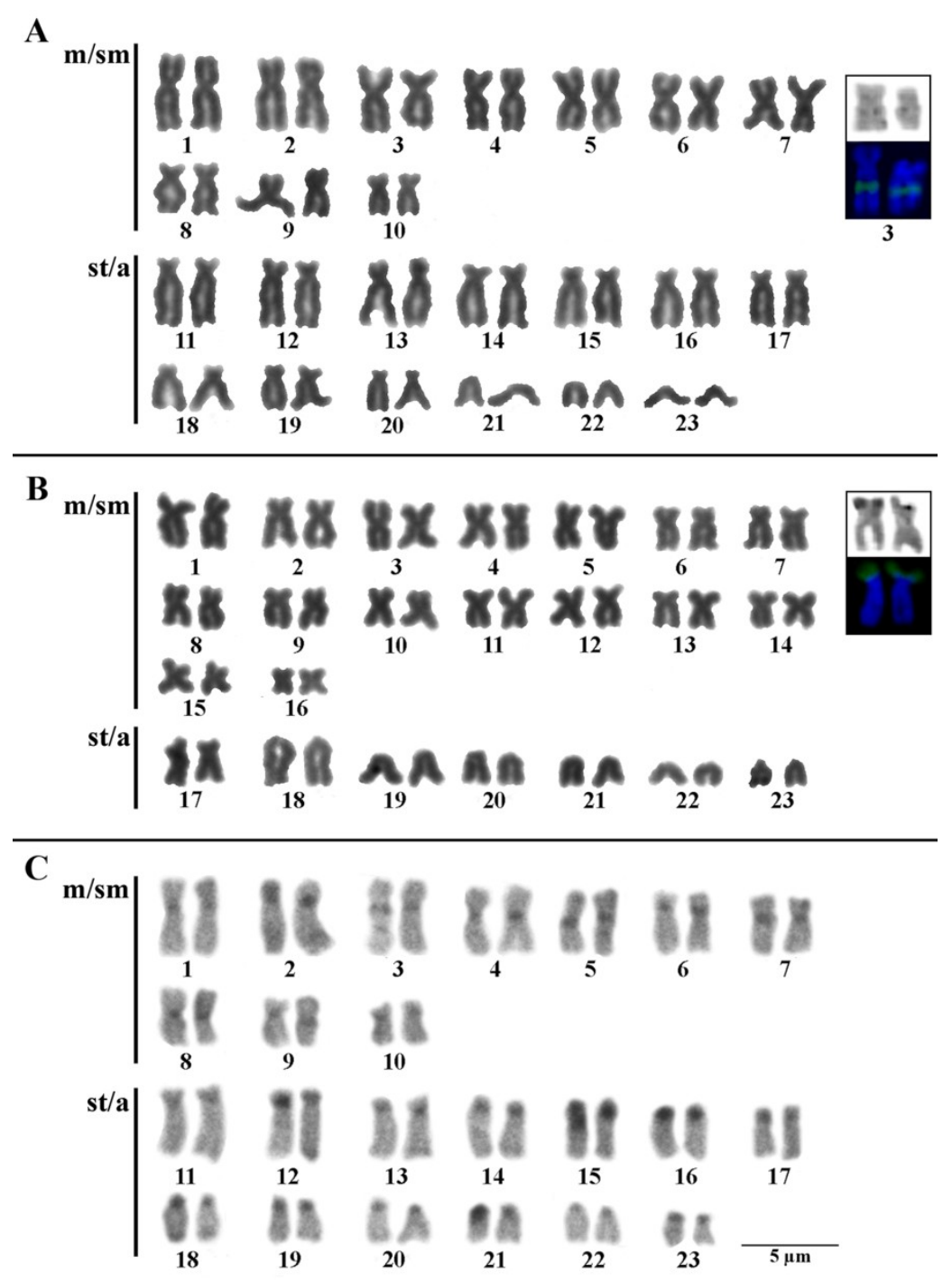

Figure 2. Conventionally stained (A, B) and C-banded (C) karyotypes of S. tesselatus (A, C) and S. plagusia (B). In detail, the NOR-bearing pairs after silver nitrate staining (Ag-NOR) and base-specific fluorochrome staining revealing GC-rich sites (CMA3+).

A single Ag-NOR system was observed in both species, located at interstitial region of long arms of the third $\mathrm{m} / \mathrm{sm}$ pair in $S$. tesselatus (Figure $2 \mathrm{~A}$, detail) and at terminal 
region on short arms of a sm pair in S. plagusia (Figure $2 \mathrm{~B}$, detail), In both species, the NORs were interspersed with GC-rich sites $\left(\mathrm{CMA}_{3}{ }^{+} / \mathrm{DAPI}^{-}\right)$(Figure $2 \mathrm{~A}$ and $\mathrm{B}$, detail).

In $S$. tesselatus, heterochromatic blocks were visualized at centromeric region of most chromosomes and interstitially in one pair, being coincident with Ag-NORs (Figure 2 C). Unfortunately, C-banding was not successful in S. plagusia.

\section{DISCUSSION}

The diploid number in representatives of Pleuronectiformes ranges from 28 to 48 , the later being reported in $40 \%$ of analyzed species. The presence of 48 chromosomes is regarded as a plesiomorphic feature of Pleuronectiformes and their karyotype diversification seems to have evolved from two main chromosomal rearrangements: centric fusions leading to reduction of $2 \mathrm{n}$ values and pericentric inversions that have increased the number of chromosomal arms (FN) (Azevedo et al., 2007; Bitencourt et al., 2014).

In addition, most of Pleuronectiformes are characterized by a single NOR-bearing pair, usually located at terminal position of biarmed chromosomes or at pericentromeric region of subtelo/acrocentric chromosomes, with few cases of multiple NORs (Azevedo et al., 2007). Invariably, NORs are interspersed with GC-rich heterochromatic blocks (Azevedo et al., 2005; Fujiwara et al., 2007; Ocalewicz et al., 2008; Bitencourt et al., 2014; Bitencourt et al., 2017). These data suggest that the changes in karyotype macrostructure are not followed by significant microstructural variations.

In Cynoglossidae (Table 1), karyotype reports are restricted to two species of Symphurus: S. tessellatus (Azevedo et al., 2007) and S. plagiusa (LeGrande, 1975). Both species share a chromosomal number close to the plesiomorphic condition $(2 \mathrm{n}=48 \mathrm{a})$, being equal to $2 \mathrm{n}=45 / 46$ in Symphurus plagiusa and $2 \mathrm{n}=46$ for $S$. tessellatus. Accordingly, a single event of centric fusion accompanied by multiple pericentric inversions could account for the karyotype formulae described in Symphurus since they present several m/sm pairs (Azevedo et al., 2007). In the case of $S$. plagiusa, a multiple sex chromosome system has been reported (LeGrande, 1975) represent a peculiar situation rarely observed in Pleuronectiformes (Bitencourt et al., 2017).

Here, we increased the cytogenetic data for Cynoglossidae by providing the first report of the karyotype structure of S. plagusia. Similar to previous reports in other species, S. plagusia presented $2 \mathrm{n}$ values lower than $48(2 \mathrm{n}=46)$ and several biarmed chromosomes $(32 \mathrm{~m} / \mathrm{sm}+14 \mathrm{st} / \mathrm{a} ; \mathrm{FN}=78)$. The high number of meta/submetacentric in this species suggests that several pericentric inversions have taken place during diversification and speciation.

On the other hand, the specimens of Symphurus tessellatus presented the same diploid number previously reported for this species $-2 n=46$ - but they differed in relation to the karyotype formulae (Azevedo et al., 2007). While the populations herein analyzed presented $20 \mathrm{~m} / \mathrm{sm}+26 \mathrm{st} / \mathrm{a}(\mathrm{FN}=66)$, the population from São Paulo (Southeastern Brazil) was characterized by $22 \mathrm{~m} / \mathrm{sm}+24 \mathrm{st} / \mathrm{a}(\mathrm{FN}=68)$ (Azevedo et al., 2007). These differentiated karyotype formulae indicate that both populations diverged in the number of pericentric inversions. Nonetheless, these subtle differences between close chromosomal categories such as submetacentric and subtelocentric might be artifactual as a result of chromosomal condensation or the criteria established by each author. Moreover, the early development stages (eggs and larvae) of Symphurus are pelagic (Aceves-Medina et al., 2006) and some reports indicate that the metamorphosis of species in this genus might take one year to be 
complete (Munroe and Krabbenhoft, 2010; Tunnicliffe et al., 2013). Therefore, this long period of pelagic stages might favor dispersal over long distances such as Northeastern and Southeastern coast of Brazil and hinder the fixation of interpopulation cytogenetic differences.

Table 1. Cytogenetic data for Cynoglossidae: diploid number (2n), fundamental number (FN) and banding techniques.

\begin{tabular}{|c|c|c|c|c|c|c|c|}
\hline Species & Locality & $2 n$ & FN & Karyotype & C-banding & Ag-NOR & Reference \\
\hline $\begin{array}{l}\text { Cynoglossus } \\
\text { semilaevis }\end{array}$ & Yantai, China & 42 & 42 & $42 \mathrm{a}$ & Interstitial & $\begin{array}{l}\text { 2nd pair } \\
\text { (telomeric } \\
\text { region; } C^{+} \text {) }\end{array}$ & $\begin{array}{l}\text { Jiang et al. } \\
(2014), \text { Di et } \\
\text { al. (2006) and } \\
\text { Zhou et al. } \\
(2005)\end{array}$ \\
\hline $\begin{array}{l}\text { Cynoglossus } \\
\text { interruptus }\end{array}$ & Yanai, Japan & 34 & 34 & $34 \mathrm{a}$ & - & - & $\begin{array}{l}\text { Sakamoto and } \\
\text { Nishikawa } \\
(1980)\end{array}$ \\
\hline \multirow{2}{*}{$\begin{array}{l}\text { Cynoglossus } \\
\text { puncticeps } \\
\text { Paraplagusia } \\
\text { bilineata }\end{array}$} & $\begin{array}{l}\text { Bengal Bay, } \\
\text { India }\end{array}$ & +39 & 40 & $1 \mathrm{~m}+38 \mathrm{a}$ & - & - & $\begin{array}{l}\text { Patro and } \\
\text { Prasad (1981) }\end{array}$ \\
\hline & $\begin{array}{l}\text { Bengal Bay, } \\
\text { India }\end{array}$ & 38 & 44 & $8 \mathrm{~m} / \mathrm{sm}+32 \mathrm{a}$ & - & - & $\begin{array}{l}\text { Patro and } \\
\text { Prasad (1981) }\end{array}$ \\
\hline $\begin{array}{l}\text { Paraplagusia } \\
\text { japonica }\end{array}$ & Futami, Japan & 38 & 46 & $6 \mathrm{~m}+32 \mathrm{st} / \mathrm{a}$ & - & - & $\begin{array}{l}\text { Sakamoto and } \\
\text { Nishikawa } \\
(1980)\end{array}$ \\
\hline \multirow{2}{*}{$\begin{array}{l}\text { Symphurus } \\
\text { plagiusa }\end{array}$} & \multirow{2}{*}{$\begin{array}{l}\text { Louisiana, } \\
\text { USA }\end{array}$} & 345 & 68 & $\begin{array}{l}\delta 23 \mathrm{~m} / \mathrm{sm}+ \\
22 \mathrm{st} / \mathrm{a}\end{array}$ & \multirow{2}{*}{-} & \multirow{2}{*}{-} & \multirow{2}{*}{$\begin{array}{l}\text { Le Grande } \\
(1975)\end{array}$} \\
\hline & & +46 & 70 & $\begin{array}{l}\text { +24 m/sm + } \\
22 \mathrm{st} / \mathrm{a}\end{array}$ & & & \\
\hline $\begin{array}{l}\text { Symphurus } \\
\text { plagusia }\end{array}$ & Paraíba, Brazil & 46 & 78 & $\begin{array}{l}32 \mathrm{~m} / \mathrm{sm}+14 \\
\text { st/a }\end{array}$ & - & $\mathrm{st} / \mathrm{a} ; \mathrm{CMA}_{3}{ }^{+}$ & Present study \\
\hline \multirow[b]{2}{*}{$\begin{array}{l}\text { Symphurus } \\
\text { tessellatus }\end{array}$} & $\begin{array}{l}\text { São Paulo, } \\
\text { Brazil }\end{array}$ & 46 & 68 & $\begin{array}{l}22 \mathrm{~m} / \mathrm{sm}+24 \\
\mathrm{st} / \mathrm{a}\end{array}$ & $\begin{array}{l}\text { Mostly } \\
\text { centromeric }\end{array}$ & \multirow{2}{*}{$\begin{array}{l}3 \mathrm{rd} \mathrm{m} / \mathrm{sm} \text { pair } \\
\text { (i/la)/; bc; } \\
\mathrm{CMA}_{3}^{+} \\
3 \mathrm{rd} \mathrm{m} / \mathrm{sm} \\
(\mathrm{i} / \mathrm{la}) ; \mathrm{bc}^{+} ; \\
\mathrm{CMA}_{3}^{+}\end{array}$} & $\begin{array}{l}\text { Azevedo et al. } \\
(2007)\end{array}$ \\
\hline & $\begin{array}{l}\text { Rio de } \\
\text { Janeiro/Bahia, } \\
\text { Brazil }\end{array}$ & 46 & 66 & $\begin{array}{l}20 \mathrm{~m} / \mathrm{sm}+ \\
26 \mathrm{st} / \mathrm{a}\end{array}$ & $\begin{array}{l}\text { Mostly } \\
\text { centromeric }\end{array}$ & & Present study \\
\hline
\end{tabular}

In this sense, the inclusion of additional chromosomal markers based on banding techniques should be useful to refine the cytogenetic analysis in Symphurus, such as those to reveal the distribution of heterochromatin and repetitive DNA clusters. In the present study, the specimens of Symphurus tessellatus were characterized by C-bands at pericentromeric region and at interstitial position of few pairs, as commonly reported in Cynoglossidae so far (Azevedo et al., 2007). Nonetheless, representatives of the families Bothidae (Vitturi et al., 1993; Argolo et al., 2018) and Achiridae (Bitencourt et al., 2014) usually present conspicuous heterochromatin segments, what seems to represent a trend for some lineages of Pleuronectiformes despite the limitations of these data for cytotaxonomic inferences.

In addition, the single NOR system associated with GC-rich sites, as presently described (Figure 2) has been widely reported in fishes (deAlmeida-Toledo et al., 1996), reptilians and amphibians (Kasahara, 2009). However, the presence of interstitial Ag-NORs 
might be interpreted as a derived feature in Pleuronectiformes (Vitturi et al., 1993; Azevedo et al., 2007), usually derived from pericentric inversions.

Again, the NOR location reported in Symphurus tesselatus from this study is similar to that reported in S. tessellatus by Azevedo et al. (2007) but they differed in relation to the presence (this study) or lack (Azevedo et al., 2007) of C-bands associated with NORs, being the former a common situation in Pleuronectiformes (Kikuno et al., 1986; Pardo, 2001; Azevedo et al., 2007; Fujiwara et al., 2007). Therefore, the C-banding might be a potential chromosomal marker to differentiate species or populations of Symphurus, what remains to be investigated.

In S. plagusia, a distinctive distribution of NORs was observed, being located at terminal region on short arms of a metacentric pair, thus differing from previous reports in this genus. These data suggest that cytogenetics is efficient to validate species of Symphurus, a group recognized by their confusing taxonomy. Based on karyotype macrostructure and conventional banding analyses we were able to recognize each taxon, being potentially useful to discriminate cryptic forms. Nonetheless, the cytogenetic data in Cynoglossidae are too scarce and further information are required to refine the role of chromosomal changes in the diversification of Symphurus species.

\section{ACKNOWLEDGMENTS}

The authors are grateful to Conselho Nacional de Desenvolvimento Científico e Tecnológico - CNPq, Coordenação de Aperfeiçoamento de Pessoal de Nível Superior CAPES (financial code 001) and Fundação de Amparo à Pesquisa do Estado da Bahia FAPESB for the financial support, ICMBio for the collection license and the Ethics Committee in the Utilization of Animals by Universidade Estadual do Sudoeste da Bahia for approval of the research.

\section{CONFLICTS OF INTEREST}

The authors declare no conflict of interest.

\section{REFERENCES}

Aceves-Medina G, Saldierna-Martínez RJ and González-Navarro EA (2006). Distribution and abundance by larval developmental stages of Symphurus williamsi (Pleuronectiformes: Cynoglossidae) in the Gulf of California. Sci. Mar. 70: 291-302.

Allendorf FW and Luikart G (2007). Conservation and the genetics of populations. John Wiley and Sons Ltd., Chichester.

Almeida-Toledo LF, Stocker AJ, Foresti F and Toledo-Filho SA (1996). Fluorescence in situ hybridization with rDNA probes on chromosomes of two nucleolus organizer region phenotypes of a species of Eigenmannia (Pisces, Gymnotoidei, Sternopygidae). Chromosome Res. 4: 30-305.

Argolo LA, Ramos RTC, Barreto SB, Bitencourt JA, et al. (2018). The flounder next door: Closer evolutionary relationship between allopatric than sympatric Bothus (Rafinesque, 1810) species (Pleuronectiformes, Bothidae). Zool. Anz. 277: 131-142.

Azevedo MFC, Oliveira C, Pardo BG, Martínez P, et al. (2005). Chromosome banding and 18S rDNA in situ hybridization analysis of seven species of the family Achiridae (Teleostei: Pleuronectiformes). Genetica. 125: 125132.

Azevedo MFC, Oliveira C, Pardo BG, Martínez P, et al. (2007). Cytogenetic characterization of six species of flatfishes with comments to karyotype differentiation patterns in Pleuronectiformes (Teleostei). J. Fish. Biol. 70: 1-15. 
Bitencourt JA, Sampaio I, Ramos RTC and Affonso PRAM (2014). Chromosomal fusion in Brazilian populations of Trinectes inscriptus Gosse, 1851 (Pleuronectiformes; Achiridae) as revealed by internal telomere sequences (ITS). J. Exp. Mar. Bio. Ecol. 452: 101-104.

Bitencourt JA, Sampaio I, Ramos RT, Vicari MR, et al. (2017). First report of sex chromosomes in Achiridae (Teleostei: Pleuronectiformes) with inferences about the origin of the multiple X1X1X2X2/X1X2Y system and dispersal of ribosomal genes in Achirus achirus. Zebrafish. 14: 90-95.

Blessing JJ, Marshall JC and Balcombe SR (2010). Humane killing of fishes for scientific research: a comparison of two methods. J. Fish. Biol. 76: 2571-2577.

Cioffi MB, Camacho JPM and Bertollo LAC (2011). Repetitive DNAs and the differentiation of sex chromosomes in Neotropical fishes. Cytogenet. Genome Res. 132: 188-194.

Cipriano RR, Fenocchio AS, Artoni RF, Molina W, et al. (2008). Chromosomal studies of five species of the marine fishes from the Paranaguá Bay and the karyotypic diversity in the marine Teleostei of the Brazilian coast. Braz. Arch. Biol. Technol. 51: 303-314.

Di W, Shicui Z, Zhimeng Z, Qiuxiang P, et al. (2006). C-banding pattern and nucleolar organizer regions of Cynoglossus semilaevis Gunther, 1873. Prog. Nat. Sci. 16: 769-772.

Farias R and Navarro A (2010). Chromosomal speciation revisited: rearranging theory with pieces of evidence. Trends Ecol. Evol. 25: 660-669.

Figueiredo L and Menezes NA (2000). Manual de peixes marinhos do sudeste do Brasil. VI. Teleostei (5). Museu de Zoologia, SãoPaulo.

Fujiwara A, Fujiwara M, Nishida-Umehara C, Abe S, et al. (2007). Characterization of Japanese flounder karyotype by chromosome bandings and fluorescence in situ hybridization with DNA markers. Genetica. 131: 267-274.

Gibson RN (2014). Introduction. In: Gibson RN, Nash RDM, Geffen AJ and Van der Veer HW. Flatfishes: biology and exploitation. $2^{\mathrm{a}}$ ed. John Wiley and Sons Ltd., Hoboken.

Guerra M (1988). Introduction to general cytogenetics. Guanabara Koogan, Rio de Janeiro.

Howell WM and Black DA (1980). Controlled silver-staining of nucleolus organizer regions with a protective colloidal developer: a 1-step method. Experientia. 36: 1014-1015.

Jiang L, Jiang J, Liu J, Yuan J, et al. (2014). Chromosome mapping of 18S rDNA and 5S rDNA by dual-color fluorescence in situ hybridization in the half-smooth tongue sole (Cynoglossus semilaevis). Genet. Mol. Res. 13: 10761-10768.

Kasahara S (2009). Introduction to Vertebrate Cytogenetics Research. $2^{\mathrm{a}}$ ed. Sociedade brasileira de genética, Ribeirão Preto.

Kikuno T, Ojima Y and Yamashita N (1986). Chromosomes of flounder, Paralichthys olivaceus. Proc. Jpn. Acad. Ser. B Phys. Biol. Sci. 62: 194-196.

Kurtz FW and Matsuura Y (2004). Early Development of Four Tonguefishes of the Genus Symphurus (Osteichthyes: Cynoglossidae) from the Southern Brazil. Jpn. J. Ichthyol. 41: 731-732.

Lee MY, Munroe TA and Kai Y (2017). Description of a new cryptic species of tonguefish (Pleuronectiformes: Cynoglossidae: Symphurus) from shallow waters off Japan. Ichthyol. Res. 64: 71-83.

Le Grande WH (1975). Karyology of six species of Louisiana Flatfishes (Pleuronectiformes: Osteichthyes). Copeia. 3: 516-522.

Levan A, Fredga KY and Sandberg AA (1964). Nomenclature for centromeric position on chromosomes. Hereditas. 52: 201-220.

Munroe TA (1991). Western Atlantic tonguefishes of the Symphurus plagusia complex (Cynoglossidae: Pleuronectiformes), with descriptions of two new species. Fish. Bull. 89: 247-287.

Munroe TA and Krabbenhoft TJ (2010). Two unusually large pre-transitional tonguefish larvae (Pleuronectiformes: Cynoglossidae: Symphurus) from oceanic waters near the Galápagos Islands. Bull. Mar. Sci. 86: 15-33.

Munroe TA (2014). Systematic diversity of the Pleuronectiformes. In: Gibson RN, Nash RDM, Geffen AJ and Van der Veer HW. Flatfishes: biology and exploitation. $2^{\mathrm{a}}$ ed. John Wiley and Sons Ltd., Hoboken.

Netto MRCB, Pauls EE and Affonso PRAM (2007). A standard protocol for obtaining fish chromosomes under postmortem conditions. Micron. 38: 214-217.

Ocalewicz K, Penman DJ and BAbiak I (2008). Variation in size and location of the Ag-NOR in the Atlantic halibut (Hippoglossus hipoglossus). Genetica. 133: 261-267.

Padial JM, Miralles A, De La Riva I and Vences M (2010). The integrative future of taxonomy. Front. Zool. 7: 16.

Pardo BG, Bouza C, Castro J, Martínez P, et al. (2001). Localization of ribosomal genes in Pleuronectiformes using Ag-, CMA 3-banding and in situ hybridization. Heredity. 86: 531-536.

Patro R and Prasad R (1981). Chromosomal studies in five Indian flatfishes. Copeia.1981: 498-503.

Sakamoto K and Nishikawa S (1980). Chromosomes of three flatfishes (Pleuronectiformes). Jpn. J. Ichthyol. 27: 268272.

Schreiber AM (2013). An asymmetric perspective on metamorphosis. In: Schreiber, A. M. Current Topics in Developmental Biology. Academic Press, Burlington.

Sumner AT (1972). A simple technique for demonstrating centromeric heterochromatin. Exp. Cell. Res. 75: 304-306.

Genetics and Molecular Research 20 (4): gmr19000 
Schweizer D (1980). Simultaneous fluorescent staining of R bands and specific heterochromatic regions (DA-DAPI bands) in human chromosomes. Cytogenet. Genome Res. 27: 190-193. DOI: https://doi.org/10.1159/000131482

Tunnicliffe V, Tyler J and Dower JF (2013). Population ecology of the tonguefish Symphurus thermophilus (Pisces; Pleuronectiformes; Cynoglossidae) at sulphur-rich hydrothermal vents on volcanoes of the northern Mariana Arc. Deep. Sea. Res. Part 2. 92: 172-182

Vitturi R, Catalano R and Colombera D (1993). Chromosome analysis of Bothus podas (Pisces, Pleuronectiformes) from the Mediterranean Sea. J. Fish. Biol. 43: 221-227.

Zhou LQ, Yang AG, Liu XZ, Du W,et al. (2005). The karyotype analysis of Cynoglossus semilaevis in China. J. Fish. China. 29: 417-419. 